\title{
BARNACLES (CRUSTACEA, CIRRIPEDIA, THORACICA) FROM THE BOHEMIAN CRETACEOUS BASIN DESCRIBED BY FRITSCH AND KAFKA (1887), WITH THE EXCLUSION OF THE FAMILY STRAMENTIDAE
}

\author{
TOMÁŠ KOČí \\ National Museum, Department of Palaeontology, Václavské nám. 68, 11579 Prague 1, the Czech Republic; protula@seznam.cz \\ MARTINA KOČOVÁ VESELSKÁ \\ Ústav geologie a paleontologie, Prírodovědecká Fakulta Univerzita Karlova v Praze, Albertov 6, 12843 Prague 2, the Czech \\ Republic; veselskamartina@gmail.com
}

JOHN W. M. JAGT

Natuurhistorisch Museum Maastricht, de Bosquetplein 6-7, 6211 KJ Maastricht, the Netherlands; john.jagt@maastricht.nl

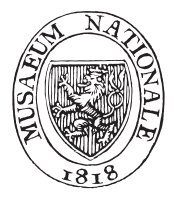

Kočí, T., Kočová Veselská M., Jagt. J. W. M. (2014): Barnacles (Crustacea, Cirripedia, Thoracica) from the Bohemian Cretaceous Basin described by Fritsch and Kafka (1887), with the exclusion of the family Stramentidae. - Acta Mus. Nat. Pragae, Ser. B, Hist. Nat., 70(3-4): 223-234, Praha. ISSN 1804-6479.

Abstract. The original types of seven cirripede taxa recorded between 1885 and 1887 by J. Kafka and A. Fritsch et J. Kafka are redescribed and reillustrated. These stalked (scalpellomorph) and sessile (brachylepadomorph) species include 'Scillaelepas' conica (REuss, 1844), Titanolepas tuberculata (DARWIN, 1851), Cretiscalpellum glabrum (ROEMER, 1841), Cretiscalpellum striatum (DARWIN, 1851), Arcoscalpellum angustatum (GEINITZ, 1843), Arcoscalpellum maximum (J. DE C. SOWERBY, 1829) and Brachylepas fallax (DARWIN, 1851). Information on the palaeoecology and taphonomy of these cirripedes in the Bohemian Cretaceous Basin (the Czech Republic) has been added.

Scalpellomorpha, Brachylepadomorpha, Cretaceous, taxonomy

Received February 27, 2014

Issued December 2014

\section{Introduction}

The first cirripedes to be recorded from the Bohemian Cretaceous Basin (BCB) in the Czech Republic are those recorded by Reuss $(1844,1845-1846,1864)$, all were from the Ohře area of the basin. Later, both Kafka (1885) and Fritsch and Kafka (1887) provided detailed accounts of cirripedes from the same area, referring also to work by Darwin (1851, 1854), Reuss (1864) and Geinitz (1843, 1845, $1875 \mathrm{a}, \mathrm{b})$. A few decades later, Withers (1935) presented a modern revision of all Cretaceous cirripedes from Europe and elsewhere; he also studied and, in part, illustrated material recorded by authors such as A. Frič (Fritsch), J. Perner and J. Šulc. Withers (1935) examined material from the following Czech localities: Kaňk, Kamajka, Na Vinici, Kučlín u Bíliny, Koštice, Duchcov, Bílá Hora, Holice, Lhota Úhřetická and Choceň, recording eleven species of cirripede, inclusive of two stramentids, viz. (in original nomenclature): Zeugmatolepas cretae (STEENSTRUP, 1837), Calantica (Scillaelepas) conica (Reuss, 1844), Calantica (Titanolepas) tuberculata (DARWIN, 1851), Cretiscalpellum glabrum (RoEMER, 1841), Cretiscalpellum striatum (DARwIN, 1851), Scalpellum (Arcoscalpellum) angustatum (GEINITZ, 1850), Scalpellum (Arcoscalpellum) maximum (J. de C. SowerbY, 1829), Loriculina laevissima (von ZitTel, 1884), Stramentum pulchellum (G. B. Sowerby, jun., 1843), Proverruca vinculum WITHERS, 1914 and Brachylepas fallax (DARWIN, 1851). Of these, Z. cretae is housed in the collections of the Natural History Museum (Department of Palaeontology, London); P. vinculum was in the J. Šulc Collection, but has been lost. The most recent papers on dissociated cirripede valves from the BCB are those by Kočí and Kočová Veselská (2012, 2013) and Kočová Veselská et al. (in prep.).

Here we revise and reillustrate material first recorded by Kafka (1885) and Fritsch and Kafka (1887), and add notes on the palaeoecology and taphonomy of cirripedes from the BCB. Table 1 lists all cirripede taxa described by those authors, their status and their current names.

Interestingly, most illustrations of cirripedes provided by Kafka (1885) and Fritsch and Kafka (1887) are the same, the majority being idealised (e.g., Brachylepas fallax). Fortunately, figures of some species, such as Cretiscalpellum striatum and Arcoscalpellum maximum, match actual specimens.

\section{Systematic palaeontology}

With a few exceptions, the taxonomic assignments below mostly follow Withers (1935), Newman et al. (1969), Babinot et al. (1979), Buckeridge (1983), Viaud et al. (1983), Zullo and Sohl (1985), Jagt and Collins (1989, 1999), Collins and Jagt (1999) and Carriol and Collins (2000, 2002). 
Table 1. Cirripede taxa recorded by Fritsch and Kafka (1887), indicating page numbers and illustrations; current names are shown in bold.

\begin{tabular}{|l|l|}
\hline Pollicipes conicus REUSS (p. 11, fig. 21) & 'Scillaelepas' conica (REUSS) \\
\hline Scalpellum tuberculatum DARWIN (p.6, fig. 9) & Titanolepas tuberculata (DARWIN) \\
\hline Scalpellum nitens KAFKA (p. 7, fig. 11) & Cretiscalpellum glabrum (ROEMER) \\
\hline Pollicipes glaber ROEMER (p. 8, fig. 13) & Cretiscalpellum glabrum (ROEMER) \\
\hline Pollicipes bronnii ROEMER (p. 9, fig. 14) & Cretiscalpellum glabrum (ROEMER) \\
\hline Pollicipes cuspidatus KAFKA (p. 11, fig. 18) & Cretiscalpellum glabrum (ROEMER) \\
\hline Pollicipes unguis SOWERBY (p. 12) & Cretiscalpellum glabrum (ROEMER) \\
\hline Pollicipes costatus KAFKA (p. 9, fig. 15) & Cretiscalpellum striatum (DARWIN) \\
\hline Pollicipes košticensis KAFKA (p. 11, fig. 19) & Cretiscalpellum striatum (DARWIN) \\
\hline Pollicipes striatus DARWIN (p. 9, fig. 16) & Cretiscalpellum striatum (DARWIN) \\
\hline Scalpellum quadratum DARWIN (p. 5, fig. 3) & Arcoscalpellum angustatum (GEINITZ) \\
\hline Scalpellum quadricarinatum REUSS (p. 5, fig. 4) & Arcoscalpellum angustatum (GEINITZ) \\
\hline Scalpellum kamajkense KAFKA (p. 5, fig. 5) & Arcoscalpellum angustatum (GEINITZ) \\
\hline Scalpellum fossula DARWIN (p. 5, fig. 6) & Arcoscalpellum angustatum (GEINITZ). \\
\hline Scalpellum maximum (SOWERBY) (p. 6, fig. 7) & Arcoscalpellum angustatum (GEINITZ) \\
\hline Scalpellum angustum DIXON (p. 6, fig. 8) & Arcoscalpellum angustatum (GEINITZ) \\
\hline Scalpellum crassum KAFKA (p. 7, fig. 10) & Arcoscalpellum angustatum (GEINITZ) \\
\hline Pollicipes elongatus STEENSTRUP (p. 11, fig. 20) & Arcoscalpellum angustatum (GEINITZ) \\
\hline Scalpellum maximum var. bohemica KAFKA (p. 6) & A. maximum (J. DE C. SOWERBY) \\
\hline Scalpellum maximum J. DE C. SOWERBY (p. 6, fig. 7) & A. maximum (J. DE C. SOWERBY) \\
\hline Pollicipes fallax DARWIN (p. 10, fig. 17) & Brachylepas fallax (DARWIN) \\
\hline
\end{tabular}

Subclass: Cirripedia BURMEISTER, 1834

Superorder: Thoracica DARwIN, 1854

Order: Scalpelliformes BuCKERIDGE ET NEWMAN, 2006

Family: Calanticidae ZevinA, 1978

Genus: Scillaelepas SeguenZA, 1876 (s. lat.)

'Scillaelepas' conica (REuss, 1844)

P1. 1, figs 1-9

*1844 Pollicipes conicus Reuss, p. 216.

1887 Pollicipes conicus Reuss: Fritsch and Kafka, p. 11, fig. 21.

1889 Pollicipes conicus Reuss: Fritsch, p. 95, text-fig. 119.

1911 Pollicipes conicus Reuss: Frič, p. 69.

1935 Calantica (Scillaelepas) conica (Reuss): Withers, p. 120, pl. 8, figs. 1-7 (with synonymy).

Material. Studied specimens from the locality of Kaňk, sold by Fritsch in 1897, and deposited in the collections of the Natural History Museum (London) comprise five scuta (NHM In. 16739-40, In. 16742-45, one carina (NHM In. 16746), one rostrum (NHM In. 16747) and four terga (NHM In. 16753-56). In addition, we also examined all material which is deposited in NHM (London) which consists of a total of 84 plates sold by Fritsch (coll. numbers are mentioned by Withers (1935, pp. 120-122)). Unfortunately, the collections of the National Museum (Prague) do not contain any material from Fritsch and Kafka's (1887) original collection.

Des c ription. For a full description, please refer to Withers (1935, pp. 120-122).
R e m arks. In his account of the 'Teplitzer Schichten' (= current Teplice Formation), Fritsch (1889) used Reuss's type specimen (1844, p. 216) from Sauerbrunnberg bei Bilina (= Kyselka u Bíliny). Fritsch and Kafka (1887) recorded the present species from the 'Priesener Schichten' (= current Březno Formation) from the locality of Luschitz, while Frič (1911) merely noted a single occurrence from Cenomanian strata (current Korycany Member) at Bílina and Kyselka u Bíliny, but did not provide an illustration. From the locality Kaňk - Na Vrších more than 500 articulated capitular plates were recently obtained from fieldwork during 2014 (T. K. and M. K. V.) and the new material pertaining to this species has recently been studied (Kočí, Kočová Veselská, Buckeridge, Jagt, Collins, Gale in prep.). It is probable that this new material represents a new genus (Gale, personal communication) and species based on the study of the holotype (T. K. and M. K. V., August 2014) which is deposited in NHMW in Vienna.

Occurrence (BCB). Upper Cenomanian (Kaňk); upper Turonian (Kyselka u Bílliny, Lužice; Březno Formation).

Overall range. Upper Cenomanian to ? Upper Turonian (or ? Coniacian; Březno Formation).

Genus: Titanolepas WITHERs, 1913

\section{Titanolepas tuberculata (DARwIN, 1851)}

$$
\text { Pl. 2, fig. } 1
$$

*1851 Scalpellum tuberculatum DARWIN, p. 43, pl. 1, fig. 10.

1887 Scalpellum tuberculatum DARWIN: Fritsch and Kafka, p. 6, fig. 9.

1935 Calantica (Titanolepas) tuberculata (DARWIN); Withers, p. 130, pl. 11, figs. 1-10; pl. 12, figs. 1-3. 
M a te ria l. A single, rather poorly preserved tergum from Kamajka (National Museum, NM O3407), Kafka's original (1885, p. 14, pl. 1, fig. 7; see also Fritsch and Kafka, 1887, p. 6, fig. 9).

D e s c r i p t i o n. Tergum diamond shaped, elongated; apicobasal ridge almost straight, prominent, thickening towards acute basal angle; conspicuous ornamentation, longitudinal ridges crossed by transverse ridges, creating short, blunt spines.

$\mathrm{R}$ e $\mathrm{m}$ a r k s. Titanolepas tuberculata can be differentiated from the younger T. subtuberculata (WITHERS, 1935) by its straight apicobasal ridge, the latter having a sigmoidally curved apicobasal ridge on the tergum. In addition, the coarse, close-set ridges are fewer and finer. Titanolepas martini (WITHERS, 1926), from the Late Cretaceous Niobrara Group, has a subrhomboidal tergum and lacks the blunt spines on the valve surface.

O c currence ( B C B ). Kamajka. Withers (1935) also listed this species from the upper Turonian of $\mathrm{Na}$ Vinici, northeast of Kolín, a locality now defunct, on the basis of the J. Sulc Collection held at the Natural History Museum (London). This lot comprises six carinae, five scuta, six terga and two lower latera. The remainder of this collection was lost during the turmoil of the Second World War. Unfortunately, the original locality is lost so we cannot determine whether a nearshore or pelagic facies was once exposed; the age has recently been documented as Middle Turonian (Zelenka et al. 2011).

Overall range. Cenomanian to Upper Turonian.

\section{Genus: Cretiscalpellum WITHERS, 1922}

\section{Cretiscalpellum glabrum (ROEMER, 1841)}

Pl. 2, fig. 2

*1841 Pollicipes glaber Roemer, p. 104, pl. 16, fig. 11a-c. 1887 Scalpellum nitens KAFKA.: Fritsch and Kafka, p. 7, fig. 11a, b.

1887 Pollicipes glaber RoEMER: Fritsch and Kafka, p. 8, fig. 13.

1887 Pollicipes Bronnii RoEmer: Fritsch and Kafka, p. 9, fig. 14a-c.

1887 Pollicipes fallax DARWIN: Fritsch and Kafka, p. 10, fig. 17 (partim).

1887 Pollicipes cuspidatus KAFKA: Fritsch and Kafka, p. 11, fig. 18 .

1887 Pollicipes unguis SOWERBY: Fritsch and Kafka, p. 12.

1889 Pollicipes glaber RoEMER: Fritsch, p. 95, fig. 117.

1887 Pollicipes bronni RoEMER: Fritsch, p. 95, fig. 118.

1893 Pollicipes glaber RoEmer: Fritsch, p. 109.

1897 Pollicipes glaber ROEMER: Fritsch, p. 70.

1935 Cretiscalpellum glabrum (F. A. ROEMER): Withers, p. 161 , pl. 15 , figs. $8-17$; pl. 16, figs. $1-10$; pl. 17 , figs. $1-21$; pl. 18, figs. $1-5$.

$\mathrm{M}$ a t e r i a l. The original carina collected by Fritsch and Kafka (1887, fig. 13), from Koštice, NM O4375 (no. 6532) in the collections of the National Museum (Prague); it measures $14.6 \mathrm{~mm}$ in length and $6.3 \mathrm{~mm}$ in basal width. Pollicipes sp./Scalpellum Frič A.,- carina and two fragments of a left tergum from Měcholupy railway station - this material was collected by Antonín Frič in 1901, unpublished data., and deposited in collection of NM, without an inventary number.

Description. Carina with broken apex, lacking parietes and intraparietes; median ridge distinct; lateral margins slightly rounded inwards; surface of carina apparently smooth, but at higher magnification distinct sharp lines parallel to basal margin become visible.

Remarks. The present species bears the closest resemblance to $C$. striatum, the carina of which has a stronger apicobasal ridge than other longitudinal lines and strongly developed transverse lines. The carina of C. bronni (RoEMER, 1841), from the Cenomanian of Germany and northwest France, has no transverse lines and the apicobasal keel is less prominent, while that of C. unguis (J. DE C. SOWERBY, 1829), from the Albian of England and France, is wider, has slightly rounded parietes and the most strongly developed transverse lines within the genus Cretiscalpellum. The early Campanian C. obtusum JAGT ET Collins, 1999 has a trapezoidal scutum that is more convex than that of C. glabrum.

O c c urrence ( B C B ). Upper Cenomanian (Velim, Přemyšlany [Přemyšlení is now part of the hamlet of Zdiby near Prague), Černovičky; Lower Turonian (Velim, Kamajka, Turkaňk, Karlov, Odolena Voda, Běstvina u Ronova nad Doubravou, Chrtníky); Middle Turonian (Semice, Bousov, Všetaty, Mikulovice near Pardubice); Upper Turonian (Koštice, Úpohlavy, Č́́žkovice, Želenice near Bílina, Kostomlaty, Radim u Luže, Teplice, Kystrá, Měcholupy); Upper Turonian - Lower Coniacian (Lužice, Lány na Důlku near Pardubice, Úhřetická Lhota); Lower - Middle Coniacian (Litomyšl).

Overall range. Upper Albian - Upper Maastrichtian.

\section{Cretiscalpellum striatum (DARWIN, 1851)}

$$
\text { P1. 2, fig. } 3
$$

*1851 Pollicipes striatus DARWIN, p. 70, pl. 4, fig. 5a-c.

1887 Pollicipes costatus KAFKA: Fritsch and Kafka, p. 9, fig. 15.

1887 Pollicipes striatus DARWIN: Fritsch and Kafka, p. 9, fig. 16.

1887 Pollicipes košticensis KAFKA: Fritsch and Kafka, p. 11, fig. 19.

1889 Pollicipes košticensis KAFKA: Fritsch, p. 95, fig. 116. 1935 Cretiscalpellum striatum (DARWIN): Withers, p. 183, pl. 20, figs. 1-5, 15-21; pls. 21, 22.

M a t e ri a 1. NM O4027 (no. 6531), the original tergum described by Kafka (1889, pl. 2, fig. 4).

Description. Tergum elongated, irregularly rhomboidal; apical umbo acute; apicobasal ridge distinct and sharply rounded; occludent margin straight; scutal margin forming angle of 50 degrees with occludent margin; longitudinal lines on carinal part of tergum clear and distinct; scutal margin formed by apicoscutal groove, ending at scutal 
margin, $2 \mathrm{~mm}$ from occludent margin; distinct transverse lines parallel to scutal margin; inner part smooth and with distinct growth lines of carinal fold near carinal margin.

R e m a r ks. The present species has a more elongated tergum than C. glabrum. The main distinguishing features are the sharp longitudinal and transverse lines; these are absent in C. glabrum. Cretiscalpellum paucistriatum (WOODWARD, 1901) has an elongated tergum, which is much less clearly longitudinally striated (almost smooth in some cases) and with a peculiar transverse convexity, while C. naidini Alekseev, 2009 has a strongly convex tergum with a very thick axial portion and a wide occludent rib. The carina of C. sharapovi AleKSEEv, 2009 has a thick-set apical part which is covered by narrow ribs which are curved into the outer side.

O c currence ( B C B ). Lower Turonian (Velim, Karlov [recorded by Žítt and Nekvasilová, 1989, p. 86, as Pollicipes costatus KAFKA], Běstvina u Ronova nad Doubravou [recorded by Žítt and Nekvasilová, 1994, p. 26, as Pollicipes costatus KAFKA]; Upper Turonian (Koštice).

Overall range. Lower Cenomanian - Upper Maastrichtian.

Family: Scalpellidae Pilsbry, 1916

Subfamily: Arcoscalpellinae ZeVINA, 1978

Genus: Arcoscalpellum HOEK, 1907

\section{Arcoscalpellum angustatum (GEINITZ, 1843)}

P1. 2, fig. 4

*1843 Pollicipes angustatus GeInITZ, p. 7, pl. 4, fig. 10.

1885 Scalpellum quadratum DARWIN: Kafka, pl. 1, fig. 1d.

1887 Scalpellum quadratum, DARWIN: Fritsch and Kafka, p. 5, fig. 3a-d.

1887 Scalpellum quadricarinatum ReUss: Fritsch and Kafka, p. 5, fig. 4a-c.

1887 Scalpellum kamajkense KAFKA: Fritsch and Kafka, p. 5, fig. 5a, b.

1887 Scalpellum fossula DARwIN: Fritsch and Kafka, p. 5, fig. $6 a, b$.

1887 Scalpellum maximum SOWERBY sp.: Fritsch and Kafka, p. 6, fig. 7c (non 7a, b).

1887 Scalpellum angustum DiXon sp.: Fritsch and Kafka, p. 6, fig. 8a-d.

1887 Scalpellum crassum KAFKA: Fritsch and Kafka, p. 7, fig. 10.

1887 Pollicipes elongatus STEEnstrup: Fritsch and Kafka, p. 11 , fig. 20a, b.

1889 Scalpellum angustatum DiXON: Fritsch, pp. 95, 96, fig. 120.

1893 Scalpellum quadratum DARWIN: Fritsch, pp. 108, 109, fig. 142.

1935 Scalpellum (Arcoscalpellum) angustatum (GEINITZ): Withers, p. 215, pl. 25, figs. 2-20; pl. 26, fig. 1.

Material. A single left scutum only (NM O 4021) survives from Fritsch and Kafka's (1887) original collection; it measures $7.7 \mathrm{~mm}$ in length and $4 \mathrm{~mm}$ in basal width.
D e s c ri p ti o n. Scutum trapezoidal, elongated; cross section slightly convex; length about twice the width; occludent margin straight or slightly curved and basal margin at right angles; edge of occludent margin bending inwards; basal margin slightly concave to straight; lateral margin extending to about two-thirds of scutal height and tergal margin to one third of scutal height; apicobasal margin distinct and rounded; towards lateral and tergal margins, area of scutum slightly sloping; lateral margin convex; tergolateral angle distinct.

R e m a rks. The present species resembles $A$. fossula (DARWIN, 1851), but differs from it in the scutal construction (see also Collins in Viaud et al. 1983). Arcoscalpellum lineatum (DARWIN, 1851), from the Upper Albian to ?Lower Santonian of England, France and Germany, differs in having longitudinal lines on the carinal tectum, narrower terga and wider scuta. The scutum of A. maximum (J. DE C. SowErBY, 1829) (see below) has a less pronounced apicobasal ridge and generally shows finer transverse and longitudinal ornamentation.

O c c u r r e n c e ( B C B ). Upper Cenomanian (Předboj, Černovičky [recorded by Žítt et al., 1999, p. 112, as Scalpellum sp.); Lower Turonian (Velim, Kamajka, Turkaňk, Kněžívka [recorded by Žítt et al., 1999, as Scalpellum crassum], Odolena Voda [recorded by Hradecká et al., 1994, p. 19, as Scalpellum crassum], Chrtníky [recorded by Žítt et al., 2006, unit 7, 8f as Scalpellid gen. et sp. indet.], Běstvina u Ronova nad Doubravou [recorded as Scalpellum sp. by Žítt and Nekvasilová, 1994, p. 26]; Middle Turonian (Všetaty); Upper Turonian (Úpohlavy, Novosedlice, Stradouň); Upper Turonian - Lower Coniacian (Lány na Důlku near Pardubice).

Overall range. Albian - Lower Santonian.

\section{Arcoscalpellum maximum (J. DE C. SOWERBY, 1829)}

\section{Pl. 2, figs. 5-7}

1829 Pollicipes maximus J. DE C. Sowerby, p. 222, pl. 606, figs. 4, 6 (non figs. 3, 5).

1885 Scalpellum maximum (SOWERBY): Kafka, p. 12, pl. 1, fig. Aa-c (non fig. 5B, C).

1886 Scalpellum maximum, var. bohemica KAFKA: Kafka, p. 564, pl. 1, fig. A (non fig. B, C).

1887 Scalpellum maximum, var. bohemica KAFKA: Fritsch and Kafka, p. 6, fig. 7a (non fig. 7b, c).

1893 Scalpellum maximum (SowERBY): Fritsch, p. 109, text-fig. 141 (incl. var. bohemica).

1935 Scalpellum (Arcoscalpellum) maximum (SOWERBY): Withers, p. 239, pl. 29, figs. 2-10; pl. 30, figs. 1-12; pl. 31, figs. 1-19.

M a te rial. The lectotype carina of var. bohemicum, $\mathrm{NM} \mathrm{O} 4022$, is from Holice. Another specimen from $\mathrm{Ku}-$ nětická Hora was collected by Jan Jiljí Jahn (see Fritsch and Kafka, 1887, p. 6).

Description. Carina with moderately to strongly convex tectum and moderately transversely arched, subcarinated and with prominent distinct narrow ridge on both sides; ridges separate tectum from parietes; parietes narrow, equalling about half tectal width, inclined outwards 
and sligthly concave; intraparietes slightly wider than the entire side of the valve side, set slightly inwards; intraparietes divided from parietes by strong distinctly rounded ridge; tectum length ranging from five to three times its width and moderately bowed inwards; wall very thin and widening gradually from apex; depth of valve approximately half width of tectum; basal margin acutely angular and inner margin almost straight.

$\mathrm{R}$ e $\mathrm{m}$ a r ks. It is interesting to note that all illustrations in the papers listed above (synonymy) are the same and all repeat the incorrect identification, as outlined by Withers (1935, p. 243). Arcoscalpellum angustatum (see above) develops only very fine apicobasal lines on the tectum and the carina is of smaller size.

Occurrence ( B C B ). Holice.

Overall range. Lower Santonian - Upper Maastrichtian.

\section{Order: Sessilia LAMARCK, 1818}

\section{Suborder: Brachylepadomorpha WITHERS, 1923}

\section{Genus: Brachylepas WoODWARD, 1901}

\section{Brachylepas fallax (DARWIN, 1851)}

Pl. 3, figs. 1a-m, 2a-g; Pl. 4, figs. 1-8

1851 Pollicipes fallax DARwin, p. 75, pl. 4, fig. 8a, b.

1885 Pollicipes fallax DARwIN: Kafka, p. 19, pl. 3, figs. 2r (non fig. 21), 3a, b (non fig. 3sl, l').

1887 Pollicipes fallax DARWIN: Fritsch and Kafka, p. 10, fig. 17 (non $\mathrm{l}^{\prime}, \mathrm{sl}$ ).

1893 Pollicipes fallax DARWIN: Fritsch, p. 309.

1935 Brachylepas fallax (DARWIN): Withers, p. 367, pl. 48 , figs. $1-24$.

Materia 1. Specimens from Uhřetická Lhota are as follows: a right scutum (NM O4023; the original from Fritsch and Kafka, 1887, fig. 17b (s), collected by J. J. Jahn), a rostrum (NM O4024; the original from Fritsch and Kafka, 1887, fig. 17r); a right scutum (NM O4025); a left scutum (NM O4026). Lot NM O4093 comprises a right tergum and four lower latera, the originals from Fritsch and Kafka, 1887, fig. 17. Lot NM-ČL6989 (nos 387, 388, 390) represents the originals from Fritsch and Kafka (1887, fig. 17t, t, c), while lot NM-ČL6990 (no. 879) comprises a scutum, a rostrum and a carina. Specimen NM-ČL6992 (Os 292), from Choceň (Sutiny), is also the original from Kafka (1885, pl. 3, 2 r).

D e s c ription. Carina semiconical, slightly bowed inwards, strongly convex transversely, yet not carinate; basal margin slightly concave; outer surface with a number of strong distinct flattened transverse ridges, regularly spaced; longitudinal ornamentation of very fine distinct longitudinal lines, preserved only in NM-ČL6989 (no. 390). The carina from Úhřetická Lhota measures $5.85 \mathrm{~mm}$ in length, while NM-ČL6989 (no. 390), which lacks the apex, measures $5 \mathrm{~mm}$ in length and $2.35 \mathrm{~mm}$ in basal width. NM-ČL6992 (Os 292), from Choceň (Sutiny), measures $5.6 \mathrm{~mm}$ in length and $2.6 \mathrm{~mm}$ in basal width. Rostrum semiconical, wider than carina, bowed inwards and strongly convex transversely; transverse ornamentation resembles that of the carina, but less pronounced. Distinct longitudinal apicobasal ridge developed. NM-ČL6990 measures c. $6 \mathrm{~mm}$ in length and c. $4.64 \mathrm{~mm}$ in basal width. Measurements (estimated because matrix partially covered) of NM O4024 are: length c. $4.5 \mathrm{~mm}$ and width c. $7 \mathrm{~mm}$. Scutum elongated triangular in outline, moderately convex transversely. Rounded, strongly convex occludent margin with acuminate apex. Apex strongly bowed towards tergum. Tergo-lateral margin slightly concave, mainly in upper part, near apex. Edge of basilateral margin protruding sharply; basilateral angle $100^{\circ}$ (NM O4025); basal margin almost straight. Rostral angle $130^{\circ}$ (NM O4025). Apicobasal ridge significantly pronounced, broad and curved convexly. Broad apicobasal ridge in NM O4026 measuring $0.45 \mathrm{~mm}$ in width. Transverse ridges significantly pronounced, equally spaced and thickened at occludent margin, narrowing near upper part of tergal margin. Overall length of right scutum NM O4023 c. $5 \mathrm{~mm}$, basal width $3.4 \mathrm{~mm}$, that of another right scutum, NM O4025, c. $6.4 \mathrm{~mm}$, basal width $5 \mathrm{~mm}$. Left scutum (NM O4026) c. $5.9 \mathrm{~mm}$, basal width $3.7 \mathrm{~mm}$. Tergum (NM-ČL6989, no. 388) subrhomboidal in outline, moderately convex transversely with prominent broad apicobasal ridge, curved towards carino-lateral margin and concave towards occludent and scutal margin. Apex acuminate, slightly bowed inwards towards occludent margin. In upper third of valve a distinct sharp concave apico-scutal ridge, parallel to apicobasal ridge. Transverse ridges prominent and equally spaced, as in scutum. Longitudinal ornamentation consisting of very fine lines. Basal angle between lateral and scutal margin $70^{\circ}$. Carinal angle between lateral and carinal margin $60^{\circ}$. Overall length $5.95 \mathrm{~mm}$.

R e m a r k s. Brachylepas has carinae, rostra, scuta, terga and upper latera that closely resemble those of Pycnolepas Withers, 1914. In fact, Withers (1914) included B. fallax in Pycnolepas. However, the latter can be differentiated by the more prominent transverse and longitudinal ridges on the carina, rostrum and upper latus, with the exception of B. naissanti (HÉBERT, 1855), which has lower L/W ratios, a semicircular basal outline and thickened inner margine (Jagt, 2007). The scutum of Pycnolepas is more elongate and the apex more acute. Brachylepas naissanti has a wide semi-conical carina and rostrum with significantly raised longitudinal ribs. The terga and scuta of $B$. naissanti have less prominent transverse sculpture than B. fallax. The imbricating plates of the latter lack longitudinal ribs and differ from those of $B$. naissanti in being more rounded at the apex. The longitudinal ribs of the imbricating plates of B. fallax are developed as furrows. Brachylepas guascoi (BOSQUET, 1857) has a wider carina with more prominent transverse ridges, a scutum with very pronounced transverse ridges and tergum with a straight apicobasal ridge nearer the scutal margin than in B. fallax. More details on the relationships between species of Brachylepas can be found in Jagt (2007). Brachylepas nervosa AleKseEv, 2009, from the upper Lower Maastrichtian of Crimea (Ukraine) has a straighter carina and rostrum and the ridge on the scutum divides the valve into two unequal parts. Alekseev (2009, p. 34) considered some western European records of B. fallax to pertain to $B$. nervosa. 
O c currence ( B C B ). Upper Turonian - Lower Coniacian (Úhřetická Lhota, Choceň (Sutiny).

Overa 11 rang e. Upper Turonian - uppermost Maastrichtian.

\section{Palaeoecology and palaeogeography}

Stalked cirripedes are relatively common faunal elements in nearshore/shallow-water facies in the $\mathrm{BCB}$, but are rare constituents of hemipelagical deposits in the area. Species lived attached to substrates in high-energy settings, near the storm wave base, an environment similar to that of representatives of the recent genus Pollicipes which occur on wave-exposed rocky shores and which are mostly intertidal in distribution (Fernandes et al., 2010).

Bathymetric records of extant members of the genus Arcoscalpellum, as mentioned by Pilsbry (1907), range between 46 and $5.365 \mathrm{~m}$. Weisbord (1977) indicated 1.555-3.028 m. Preservation of shallow water taxa is inhibited by a higher energy environment, thus completely preserved capitula of cirripedes are rare. In nearshore/ shallow-water and hemipelagic facies in the $\mathrm{BCB}$, ciripedes occur exclusively as disarticulated valves, the commonest being carinae, scuta, rostra and terga. Upper latera, carinal latera and rostral latera are rare. A single exception is Brachylepas fallax (see P1. 3a; NM-ČL6990, no. 879) which comprises a number of plates that probably belonged to three separate individuals. These capitular plates were not displaced after decomposition of the capitula and covered by sediment immediately afterwards as was more usual. This kind of preservation is recorded here for the first time from the BCB. For specimens with strongly connected (articulated) capitular plates to be preserved more or less intact, tranquil environments, rapid burial and absence of subsequent scavenging/burrowing would be required. With the exception of the genus Stramentum, cirripedes from the BCB have never been found as articulated capitula, in contrast to occurrences in the Upper Cretaceous in northwest Europe, e.g., of Arcoscalpellum unguis, A. fossula, A. maximum, Zeugmatolepas mockleri, Brachylepas naissanti and others (see e.g., Withers, 1935).

'Scillaelepas' conica, Titanolepas tuberculata, Cretiscalpellum striatum, Arcoscalpellum maximum and Brachylepas fallax are comparatively rare in the $\mathrm{BCB}$, while C. glabrum and A. angustatum are more abundant. All of these species occur widely across Europe.

\section{Acknowledgements}

We thank J. S. H. Collins (The Natural History Museum, London) for supplying items of literature, C. Mellish and H. Taylor (The Natural History Museum, London) for arranging photographs of material purchased from Fritsch in 1893, J. Sklenář (National Museum, Prague) and Martina Aubrechtová (National Museum, Prague) for allowing access to Fritsch's types and preparation of most of the photographs. We thank M. Hyžný and Thomas Nichterl (NHMW) for acces to the NHMW in Viena (August 2014). We indebted to J. S. Buckeridge (RMIT University, Melbourne) and A. S. Gale (University of Portsmouth, Portsmouth) for their constructive reviews, helpful points and comments which improved text.This research has been supported by grants GAUK n. 330211 and student grant SVV 261203 and project DKRVO 2013/05 (National Museum, 00023272).

\section{References}

Alekseev, A. S. (2009): Usonogie raki (Cirripedia, Thoracica) verchnego mela Mangyshlaka. Byulleten' Moskovskogo obščestva ispisatelei prirody. Otdel Geologicheskii, 84(2): 23-38. (in Russian, with English summary)

Babinot, J. F., Collins, J. S. H., Tronchetti, G. (1979): Calantica (Titanolepas) ambigua nov. sp.: a new cirripede from the Cenomanian of southeastern France.- Géologie Méditerrannée, 6(3): 395-402.

Bosquet, J. (1854): Les crustacés fossiles du Terrain Crétacé du Duché de Limbourg. - Verhandelingen van de Commissie belast met het Vervaardigen eener Geologische Beschrijving en Kaart van Nederland, 2: 13-137.

Buckeridge, J. S. (1983): The fossil barnacles (Cirripedia: Thoracica) of New Zealand and Australia. - New Zealand Geological Survey, Paleontological Bulletin, 50: 1-51.

Buckeridge, J. S., Newman, W. A. (2006): A revision of the Iblidae and the stalked barnacles (Crustacea: Cirripedia: Thoracica), including new ordinal, familial and generic taxa, and two new species from New Zealand and Tasmanian waters. - Zootaxa, 1136: 1-38.

Burmeister, K. (1834): Beiträge zur Naturgesichte der Rankenfüsser (Cirripedia). - G. Reimer, Berlin, 60 pp.

Carriol, R. P., Collins, J. S. H. (2000): New records of cirripedes (Crustacea, Thoracica) from the Albian of Yonne (France). - Bulletin of the Mizunami Fossil Museum, 27: 141-145.

Carriol, R. P., Collins, J. S. H. (2002): Nouvelle découverte de Cirripèdes (Crustacea, Thoracica) dans 1'Albien de 1'Yonne (France). - Bulletin de 1'Assoc.géologique Auboise, 23: 3-10.

Collins, J. S. H., Jagt, J. W. M. (1999): New Late Cretaceous cirripede records from the Liège-Limburg basin (northeast Belgium). - Bulletin de l'Institut royal des Sciences naturelles de Belgique, Sciences de la Terre, 69: 155-163.

Darwin, C. (1851): A monograph on the fossil Lepadidae, or pedunculated cirripedes of Great Britain. - Palaeontographical Society, London, vi +88 pp.

Darwin, C. (1854): A Monograph on the Sub-class Cirrripedia, with Figures of all the Species. The Balanidae, andc., [Synopsis et Index systematicus, Lepadidae, pp. 626-640] London, viii+ 684 pp.

Fernandes, J. N., Cruz, T., Syoc, van R. (2010): Pollicipes caboverdensis sp. nov. (Crustacea: Cirripedia: Scalpelliformes), an intertidal barnacle from the Cape Verde Islands. - Zootaxa, 2557: 29-38.

Frič, A. (1911): Studie v oboru českého útvaru křídového. Illustrovaný seznam zkamenělin cenomanních vrstev korycanských. - Archiv pro prŕrodovědecký výzkum Čech, 15: 1-101.

Fritsch, A. (1877): Studien im Gebiete der Böhmischen Kreideformation. II. Die Weissenbergeer und Malnitzer Schichten. - Archiv Naturwissenschaftl Landesdurchforschung von Böhmen, 4: 1-151. 
Fritsch, A. (1889): Studien im Gebiete der Böhmischen Kreideformation. IV. Die Teplitzer Schichten. Archiv Naturwissenschaftl Landesdesdurchforschung von Böhmen, 7: 1-120.

Fritsch, A. (1893): Studien im Gebiete der Böhmischen Kreideformation. V. Die Priesener Schichten. - Archiv Naturwissenschaftl Landesdurchforschung von Böhmen, 9: $1-134$.

Fritsch, A. (1897): Studien im Gebiete der Böhmischen Kreideformation. VI. Die Chlomeker Schichten. - Archiv Naturwissenschaftl Landesdurchforschung von Böhmen, 10: $1-84$

Fritsch, A., Kafka, J. (1887): Die Crustaceen der Böhmischen Kreideformation. - Selbstverlag, in Commission von Fr. Řivnáč, Praha, 53 pp.

Geinitz, H. B. (1843): Die Versteinerungen von Kieslingswalda und Nachtrag zur Characteristik des SächsischBöhmischen Kreidegebirges. - Arnoldischen Buchhandlung, Dresden/Leipzig, 23 pp.

Geinitz, H. B. (1845): Grundriss der Versteinerungskunde, 8(2): 1-815. Arnoldischen Buchhandlung, Dresden, Leipzig.

Geinitz, H. B. (1875a): Das Elbthalgebirge in Sachsen. Erster Theil: Der untere Quader. -Palaeontographica, 20(1): 288-289.

Geinitz, H. B. (1875b): Das Elbthalgebirge in Sachsen. Zweiter Theil: Der mittlere und obere Quader. Palaeontographica, 20(2): 202-204.

Hradecká, L., Nekvasilová, O., Žítt, J. (1994): Geologie a paleontologie lokality Odolena Voda (transgrese svrchnokrrídových sedimentů na skalnaté pobřeží, fosfority, přitmelení epibionti). - Bohemia Centralis, 23: 15-22.

Jagt, J. W. M. (2007): A Maastrichtian (Late Cretaceous) record of the brachylepadid cirripede genus Pycnolepas from northeast Belgium. - Neues Jahrbuch für Geologie und Paläontologie Abhandlungen, 245: 253-261.

Jagt, J. W. M., Collins, J. S. H. (1989): Upper Cretaceous cirripedes from N. E. Belgium. -Proceedings of the Geologists' Association, 100: 183-196.

Jagt, J. W. M., Collins, J. S. H. (1999): Log-associated late Maastrichtian cirripedes from northeast Belgium. Paläontologische Zeitschrift, 73(1-2): 99-111.

Kafka, J. (1885): Př́íspěvek ku poznání Cirripedů českého útvaru křídového. - Královská Česká společnost nauk, Praha, pp. 1-29.

Kočí, T., Kočová Veselská, M. (2012): Předběžná zpráva o cirripedech (Thoracica, Scalpellidae) z príbojové lokality Velim-Skalka (svrchní cenoman-spodní turon, česká křídová pánev). Geoscience Research Reports for 2011: 128-131. ČGS.

Kočí, T., Kočová Veselská, M. (2013): Nové nálezy svijonožců (Cirripedia) z př́bojové lokality Velim (kolínská oblast česká křídová pánev, svrchní cenoman-spodní turon. - Vlastivědný Zpravodaj Polabí, 43 (for 2012): 81-132.

Kočová Veselská, M., Kočí, T., Collins, J. S. H., Gale, A. S. (in prep.): A new species of Zeugmatolepas (Crustacea, Cirripedia) from the near-shore/shallow water locality at Velim, in the Bohemian Cretaceous Basin (Upper Cenomanian-Lower Turonian).
Newman, W. A., Zullo, V. A., Withers, T. H. (1969): Cirripedia. - In: Moore, R. C. (ed.). Treatise on Invertebrate Paleontology, Part R, Arthropoda, 4(1): R206-R295. Geological Society of America, Boulder/The University of Kansas Press, Lawrence.

Pilsbry, H. A. (1907): The barnacles (Cirripedia) contained in the collections of the U. S. National Museum. Bulletin of the United States National Museum, 60: $1-122$.

Pilsbry, H. A. (1916): The sessile barnacles (Cirripedia) contained in the collection of the U. S. National Museum; including a monograph of the American species. Bulletin of the United States National Museum, 93: i-xii $+1-366$.

Reuss, A. E. (1844): Geognostische Skizzen aus Böhmen. Das Kreidegebirge des westlichen Böhmens, ein monographischer Versuch, 2. - C. W. Medau, Prag, 304 pp.

Reuss, A. E. (1845-1846): Die Versteinerungen der Böhmischen Kreideformation. - vol. 1: 1-58 (1845); vol. 2: 1-140 (1846). E. Schweizerbart'sche Verlagbuchhandlung und Druckerel, Stuttgart.

Reuss, A. E. (1864): Ueber fossile Lepadiden. Sitzungsberichte der Akad der Wissenschaften zu Wien, (1)49: 215-246.

Roemer, F. A. (1840-1841): Die Versteinerungen des Norddeutschen Kreidegebirges. - Hahn'sche Hofbuchhandlung, Hannover, 145 pp.

Seguenza, G. (1876): Ricerce paleontologiche intorno ai Cirripedi tertiarii della Provincia di Messina. Noc appendice intorno ai Cirripedi viventi nel Mediterraneo, e sui fossili terziarii dell'Italia meridionale, Pt ii. - Atti della Accademia Pontaniana, 10: 265-481.

Sowerby, G. B. Jr. (1843): Description of a new fossil cirripede from the Upper Chalk near Rochester. - The Annals and Magazine of Natural History, 1(12): 260-261.

Sowerby, J. de C. (1829): The mineral conchology of Great Britain, 6. - (The author), London, $230 \mathrm{pp}$.

Steenstrup, J. (1837): Om Forverdens Dyrarter af de tvende Familier Anatiferidae (Gray) og Pollicipedidae (Gray). Krøyer Naturhistoriske Tidsskrift 1: 358-366.

Viaud, J. M., Azéma, C., Collins, J. S. H., Damotte, R., Monciardini, C. (1983): Premières données concernant les Cirripèdes du Crétacé supérieur de Vendée. Foraminifères, Ostracodes et Microflore associés. - Géologie de la France, (2)4: 321-344.

Weisbord, N. E. (1977): Scalpellid barnacles (Cirripedia) of Florida and of surrounding waters. - Bulletins of American Paleontology, 68: 169-233.

Withers, T. H. (1914): A new Cirripede from the Cenomanian Chalk Marl of Cambridge. - Geological Magazine London (dec vi), 1: 494-497.

Withers, T. H. (1935): Catalogue of fossil Cirripedia in the Department of Geology. Volume II, Cretaceous. Trustees of the British Museum (Natural History), London, 534 pp.

Zelenka, P., Dušek, K., Holásek, O., Hradecká, L., Kadlecová, R., Klečák, J., Lochmann, Z., Manová, M., Minaříková, D., Nekovařík, Č., Rejchrt, M., Šalanský, K., Štědrá, V., Švecová, J. (2011): Základní geologická mapa České republiky 1:25000 s Vysvětlivkami list 13-322 Kolín. Česká geologická služba, Praha, 68 pp. 
Zevina, G. B. (1978): A new classification of the family Scalpellidae Pilsbry (Cirripedia: Thoracica), Part 1. Subfamilies Lithotryinae, Calanticinae, Pollicipinae, Scalpellinae, Brochiinae and Scalpellipsinae. - Zoologicheskiy Zhurnal, 57: 998-1007. (in Russian)

Zittel, K. A. von (1884): Bemerkungen über einige fossile Lepadiden aus dem lithographischen Schiefer und der oberen Kriede. - Sitzungsberichte Bayerische Akademie der Wissenschaften, 14: 577-589.

Zullo, V. A., Sohl, N. F. (1985): Scalpelloid barnacles from the Upper Cretaceous of southeastern North Carolina. Proceedings of the Biological Society of Washington, 98(3): 636-643.

Žítt, J., Nekvasilová, O. (1989): Paleontologicko-geologická charakteristika navrhovaného CHPV Karlov (Kutná Hora). - Bohemia Centralis, 18: 15-40.

Žítt, J., Nekvasilová, O. (1994): Běstvina u Ronova nad Doubravou - pozoruhodný výskyt spodnoturonských foílií v př́ibřežních sedimentech české křídové pánve (Kolínská litofaciální oblast). - Bohemia Centralis, 23: 23-30.

Žítt, J., Nekvasilová, O., Hradecká, L., Svobodová, M. and Záruba, B. (1999): Rocky coast facies of the Unhošt'-Tursko High (late Cenomanian-early Turonian, Bohemian Cretaceous Basin). - Acta Musei Nationalis Pragae, ser. B Historia Naturalis [Sbornik Národního Muzea v Praze, řada B, Př́rodní vědy], 54: 79-116.

Žítt, J., Vodrážka, R., Hradecká, L., Svobodová, M. and Zágoršek, K. (2006): Late Cretaceous environments and communities as recorded at Chrtníky (Bohemian Cretaceous Basin, Czech Republic). Bulletin of Geosciences, 81: 43-79.

\section{Explanation of the plates}

\section{PLATE 1}

'Scillaelepas' conica (REUss), Kaňk, collection of the Natural History Museum, London.

1a. Scutum (external part, NHM In. 16742); 1b. Scutum (inner part, NHM In. 16742); 2a. Scutum (external part, NHM In. 16743); 2b. Scutum (inner part, NHM In. 16743); 3a. Scutum (external part, NHM In. 16744); 3b. Scutum (inner part, NHM In. 16744); 4a. Scutum (external part, NHM In. 16745); 4b. Scutum (inner part, NHM In. 16745); 5a. Scutum (external part, NHM In. 16739); 5b. Scutum (inner part, NHM In. 16740); 6. Tergum (external part, NHM In. 16753); 7. Tergum (external part, NHM In. 16754); 8a. Carina (external part, NHM In. 16746); 8b. Carina (inner part, NHM In. 16746); 9a. Rostrum (inner part, NHM In. 16747); 9b. Rostrum (external part, NHM In. 16747). All scale bars equal $1 \mathrm{~mm}$. Photographs by H. Taylor (Natural History Museum, London).

\section{PLATE 2}

1. Titanolepas tuberculata (DARWIN), Kamajka (NM O3407), partial tergum. Scale bar $=0.5 \mathrm{~mm}$.

2. Cretiscalpellum glabrum (RoEMER), Koštice (NM O4375, no. 6532), carina. Scale bar $=5 \mathrm{~mm}$.
3. Cretiscalpellum striatum (DARWIN), Koštice (NM O4027), tergum. Scale bar $=1 \mathrm{~mm}$.

4. Arcoscalpellum angustatum (GeInitz), Lány na Důlku near Pardubice (collected by Jan J. Jahn; NM O4021), left scutum. Scale bar $=5 \mathrm{~mm}$.

5-7. Arcoscalpellum maximum var. bohemicum KAFKA, from Holice (NM O4022), carina. Scale bar $=1 \mathrm{~mm}$.

(Figs 2-7 photographed by Jan Sklenár and Martina Aubrechtová, 2014; all others by the authors)

\section{PLATE 3}

1. Brachylepas fallax (DARWIN), figured specimen from Fritsch and Kafka (1887, p. 10, fig. 17), Úhřetická Lhota (NM-ČL6990, no. 879). Scale bar $=5 \mathrm{~mm}$.

a. Carina; b. Right tergum; c. Fragmentary right scutum; d. Left scutum; e. Fragmentary indeterminate valve; f. Left tergum (imprint); g. Right tergum (imprint); h. Right scutum; ch. ?Upper latus (imprint); i. Right tergum; j. Left scutum; k. Fragmentary ?rostrum; l. Fragmentary ?left tergum.

2. Brachylepas fallax, (DARWIN), NM O4893. Scale bar = $1 \mathrm{~mm}$.

a. Fragmentary right scutum; b. Fragmentary scutum; c. Rostrum; d. Right scutum; e. Indeterminate valve (imprint).

(Fig. A photographed by Jan Sklenář, 2013; Fig. B by the authors)

\section{PLATE 4}

Brachylepas fallax (DARWIN), Úhřetická Lhota.

1. Right sputum, NM O4023;

2. Rostrum and left sputum, NM O4024;

3. Left sputum, NM O4025;

4. Right sputum, NM O4026;

5. Carina, NM-ČL6989, no. 390;

6. Left tergum with crushed apex, NM-ČL6989, no. 387;

7. Carina, NM-ČL6990, no. 879;

8. Right tergum, NM- ČL6989, no. 388.

All scale bars equal $1 \mathrm{~mm}$.

(Photographs by Jan Sklenář and Martina Aubrechtová, 2014) 
PLATE 1
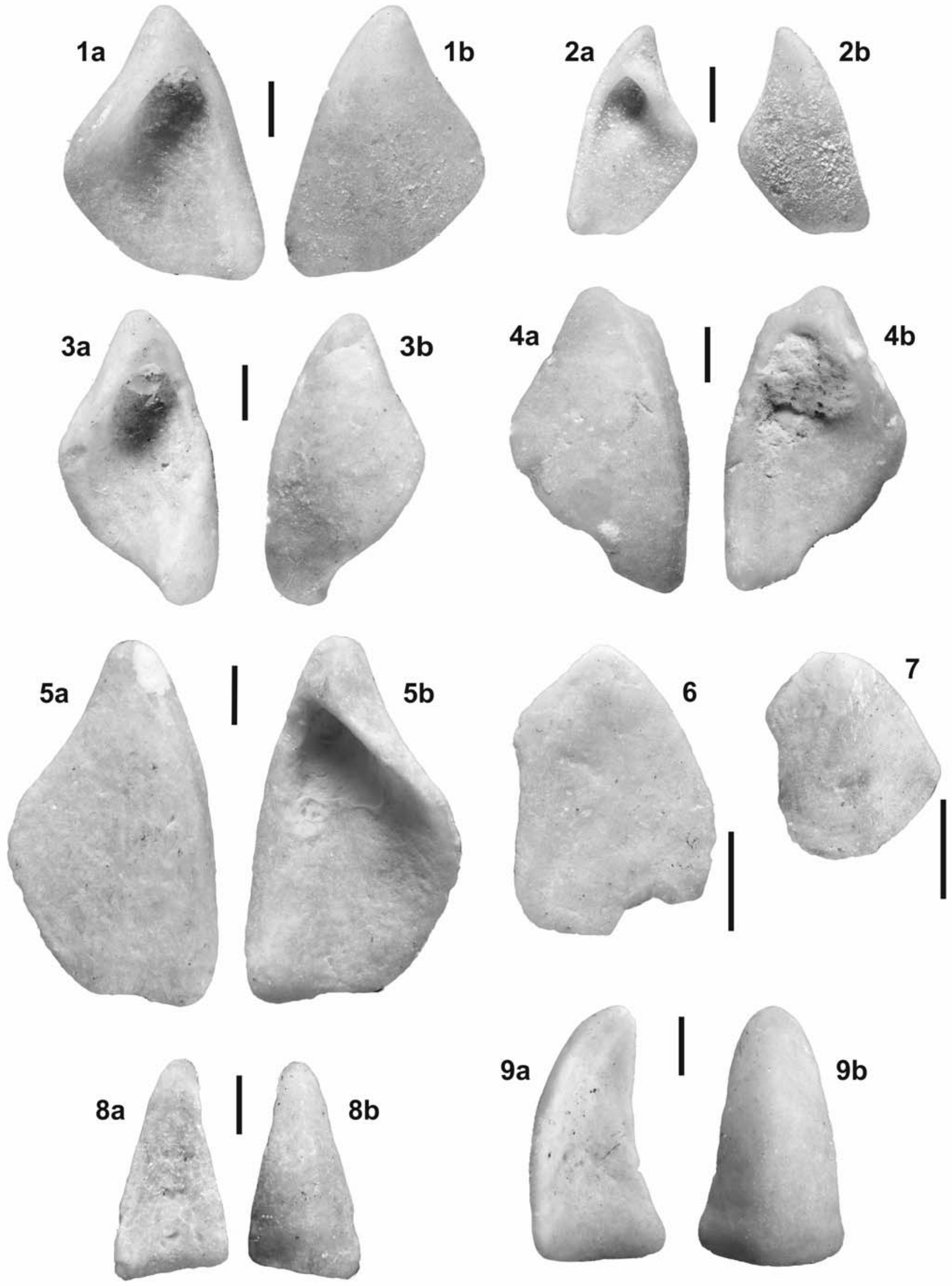
PLATE 2
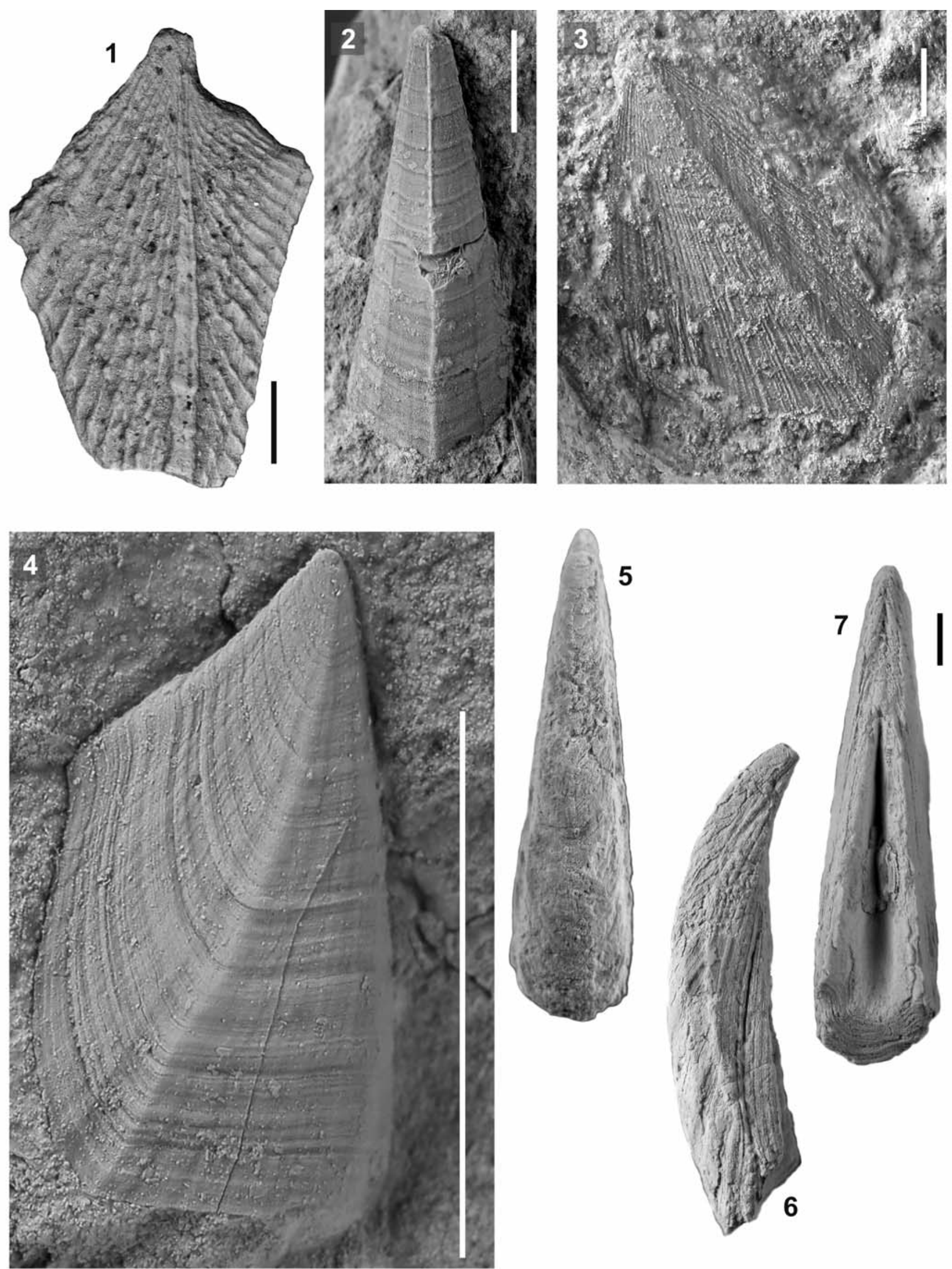

5

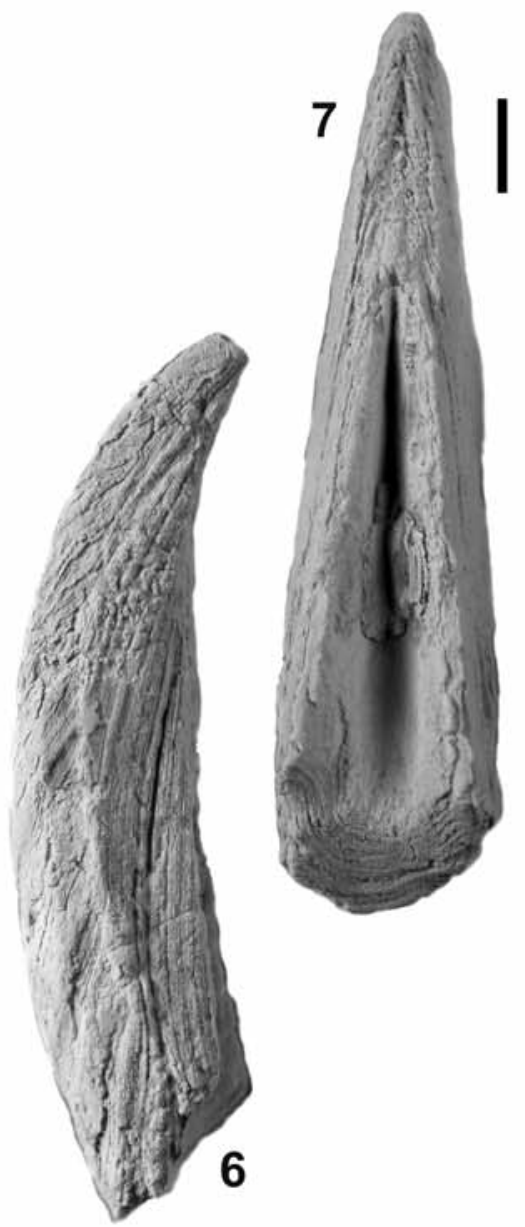


PLATE 3

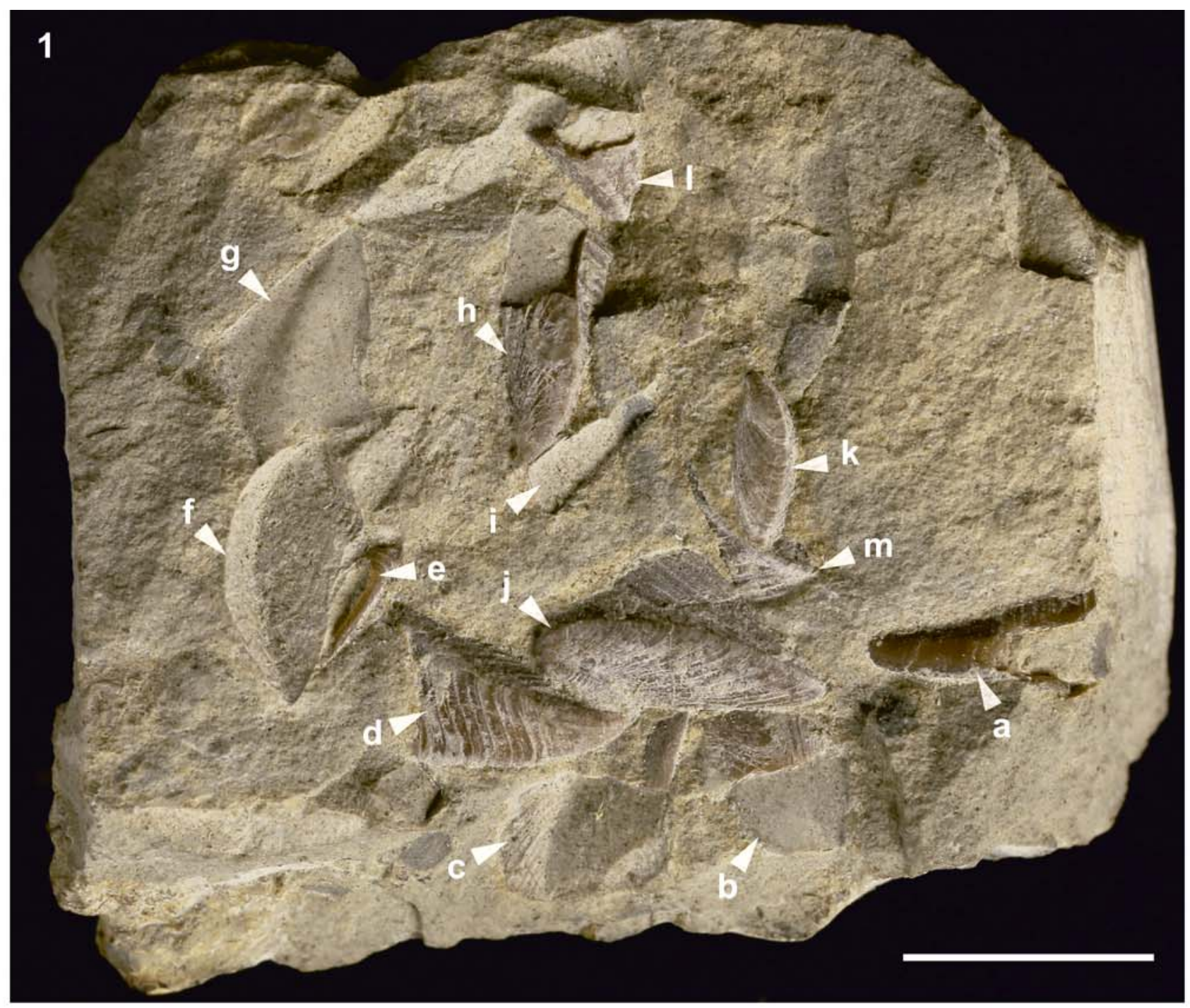

2

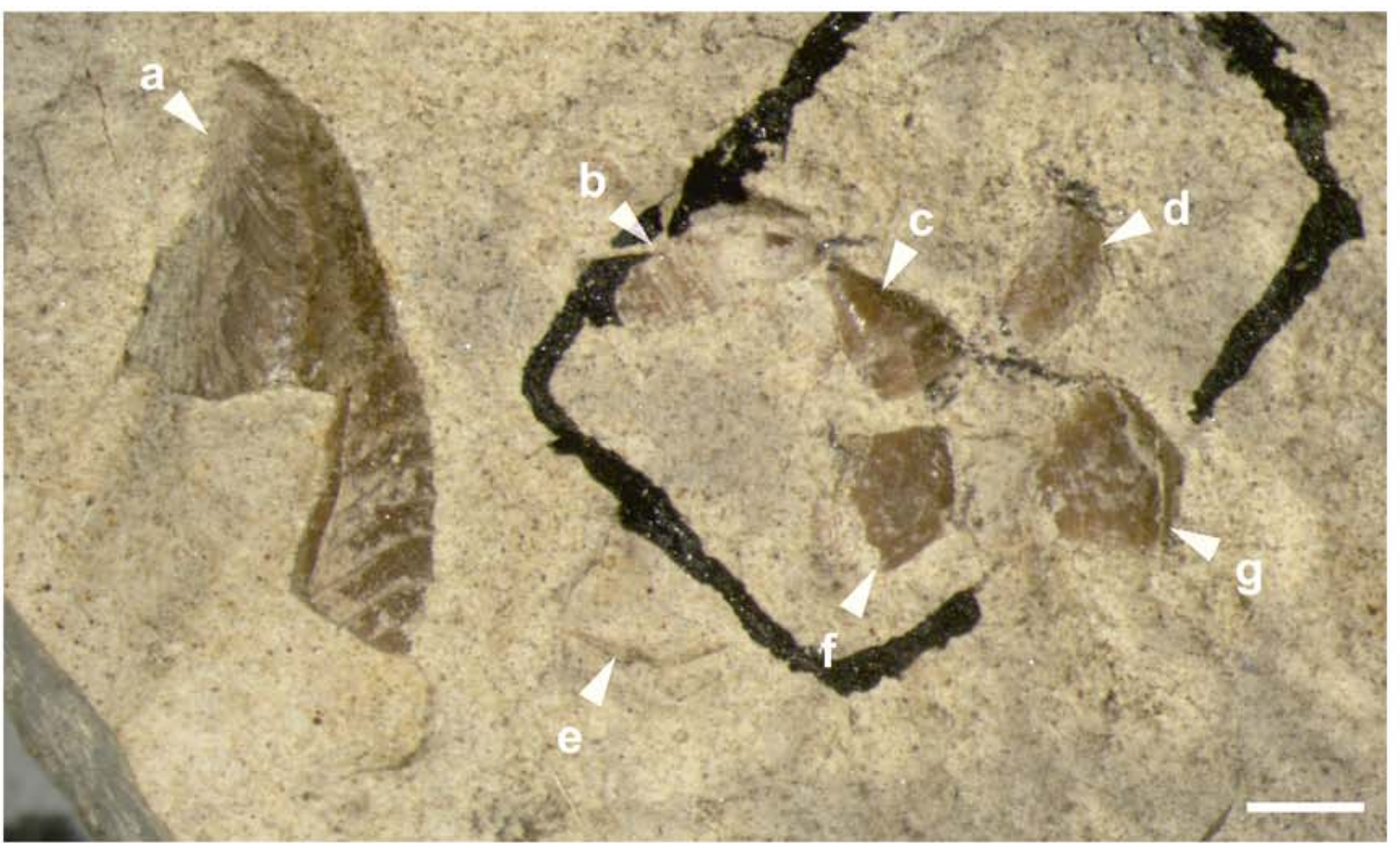




\section{PLATE 4}
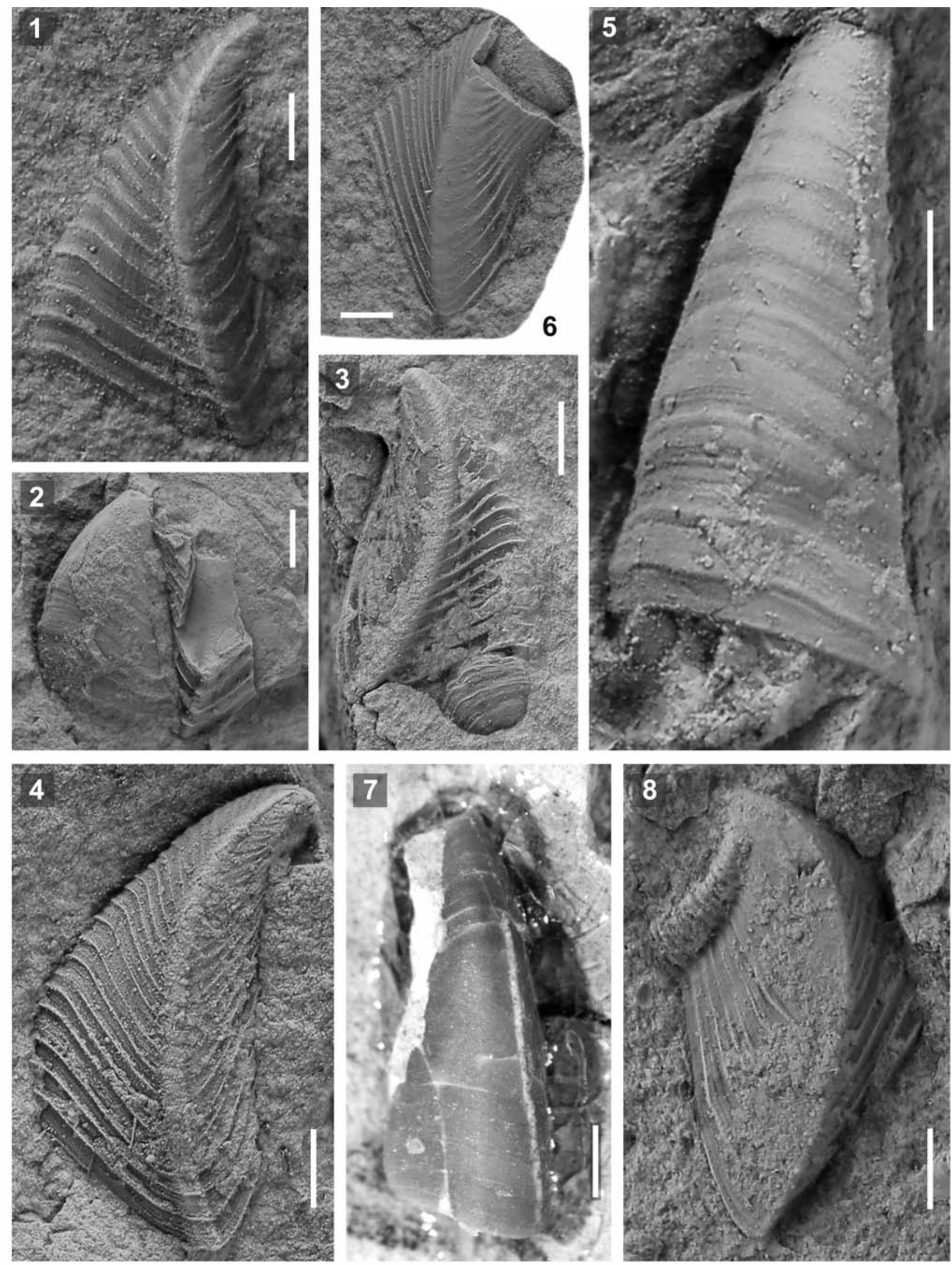